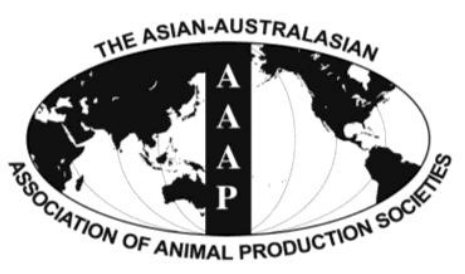

Open Access

Asian Australas. J. Anim. Sci.

Vol. 27, No. 11 : 1593-1599 November 2014

http://dx.doi.org/10.5713/ajas.2013.13712

www.ajas.info

pISSN 1011-2367 elSSN 1976-5517

\title{
Effect of Production Phase on Growth, Enzyme Activities and Feed Selection of Broilers Raised on Vegetable Protein Diet
}

\author{
M. A. Hossain, A. F. Islam, and P. A. Iji* \\ School of Environmental and Rural Science, University of New England, Armidale, NSW 2351, Australia
}

\begin{abstract}
This study consisted of two experiments, conducted to assess the impact of phase at which vegetable protein (VP) diets are introduced to broiler chicks, and preference of birds for diets based on soybean or canola meal (CM). Two hundred and ten day-old Cobb 500 chicks were randomly distributed into five dietary groups in the main experiment. One group was fed on animal protein (AP) diet all through to 21 days of age; two other groups were started on AP diet for 7 days and then switched to diets containing soybean meal (AP-SBM) or AP-CM, while two other diets (SBM-AP and CM-AP) were started on one of the VP diets for 7 days and then switched to AP diet. A sub-experiment on thirty birds raised on a commercial diet to 7 days was used in a feed selection test to quantify the preference of birds for the diets containing mainly CM or SBM. Chicks were reared under similar care and management conditions and the diets were iso-caloric and iso-nitrogenous. Results of the main experiment showed that chicks on CM-AP diet ate more (p<0.05) than those on the other diets up to day 7. Body weight gain was highest $(\mathrm{p}<0.001)$ on the AP-SBM diet while birds on the CM-AP diet weighed the least at $7 \mathrm{~d}$. Feed intake, body weight gain, feed conversion ratio, mortality, bone growth, visceral organ development, and activities of digestive enzymes were similar between the groups from hatch to 21 days of age. Results of the second sub-experiment showed that chicks preferred the CM-based diets to the SBM-based diets at 8 to $14 \mathrm{~d}(\mathrm{p}<0.001)$ and 15 to $21 \mathrm{~d}$ ( $\mathrm{p}<0.01)$ when given a choice. Overall, the birds were not affected by the nature of the starter diet although they tended to prefer the canola to soybean diets. (Key Words: Broiler Chickens, Feed Selection, Growth, Vegetable Protein, Visceral Organs)
\end{abstract}

\section{INTRODUCTION}

In chicks, the development of the digestive system is much faster than the rest of the body immediately after hatch. The gastro-intestinal tract (GIT) is completely formed at the embryonic stage (Moran, 1985), although it becomes fully functional within a few days after hatching (Nitsan et al., 1991; Iji et al., 2001a,b). This post-hatch development is very important for future performance through efficient feed utilization and growth (Faria et al., 2005). Therefore the provision of high quality nutrition to chicks in early life is necessary, to ensure the rapid development of the GIT and the rest of the body. Protein appears to be the most essential component of such nutrition, as it drives the initial intestinal development and

\footnotetext{
* Corresponding Author: P. A. Iji. Tel: +61-2-6773-2082, Fax: +61-2-6773-3922, E-mail: piji@une.edu.au

Submitted Nov. 9, 2013; Revised Jan. 8, 2014; Accepted Mar. 31, 2014
}

muscle attachments in later phases (Hargis and Creger, 1980). The quality and therefore the source of such protein may be important. This was demonstrated by differences in growth performance of the birds on diets based on vegetable protein (VP) compared to animal protein (AP) diets (Hossain et al., 2012; 2013a).

It is generally assumed that no two protein sources are similar in characteristics. The pattern of digestibility, biological value, quality, physical or chemical structure or properties of protein sources vary widely between sources. These characteristics of individual protein ingredients may affect neonatal intestinal development and function, and thus subsequent performance of the broiler chickens. The interaction between dietary nutrients, intestinal growth, and digestive function is crucial during the post-hatch period (Ullah et al., 2012). Many things in addition to nutrient processing by the GIT determine the amounts of nutrients that are available to the birds for maintenance and growth. The efficiency of nutrient supply to the body would be

Copyright @ 2014 by Asian-Australasian Journal of Animal Sciences This is an open-access article distributed under the terms of the Creative Commons Attribution Non-Commercial License (http://creativecommons.org/licenses/by-nc/3.0/), which permits unrestricted non-commercial use, distribution, and reproduction in any medium, provided the original work is properly cited. 
dependent on dietary factors, including dietary energy and protein contents (Swatson et al., 2003). Feed management, feeding behaviour, diet preference or selection by the animal may also affect feed consumption and growth of the birds.

The ancestors of modern meat chickens lived in selfselecting feeding systems. Within this system of rearing, they have a choice or opportunity to select their own feed. There is a need to explore alternative strategies in which meat chickens are able to select an appropriate mixture from a wide variety of available feedstuffs or diets. Freechoice feeding can be adopted as an alternative to regular system to meet the nutrient needs of broilers. Most choicefeeding studies have shown that feed selection by birds is regulated firstly towards satisfaction of energy requirement for growth and development (Mastika and Cumming 1981; Mastika, 1983). Birds can select a balanced amount of amino acids, avoiding amino acid deficiency or amino acid toxicity (Noble et al., 1993; Picard et al., 1997), but they may fail to balance their amino acids or proteins when energy is the limiting factor in the diet. However, as feed is the most expensive of all the variable-cost inputs required for poultry production, a self-selection feeding regime may offer a potential beneficial effect for achieving optimum production through reduction in feed costs (Zulkifli et al., 2001). The objectives of this study were to assess the impact of stage at which VP or AP diets are introduced to young broiler chicks on subsequent growth and their preference for the two main VP sources, soybean and canola, used by the poultry industry.

\section{MATERIALS AND METHODS}

Two experiments were conducted simultaneously with a total of 240 day-old male broiler chicks (Cobb 500) from hatch to 21 days. In the main experiment, 210 chicks were assigned to five dietary groups i.e. AP, fed on AP diet from hatch to 21 days of age; AP-SBM and AP-CM, fed on AP for 7 days and then switched to diets with predominantly soybean meal $(\mathrm{SBM})$ or canola meal $(\mathrm{CM})$, respectively, as protein source; SBM-AP or CM-AP, fed on a diet with soybean or canola as main protein source for 7 days and then switched to AP diet. Details of these treatments are shown in Table 1. Each diet group was replicated 6 times, 7 birds per replicate in a completely randomized design. A total of 30 brooder cages of similar size $(42 \times 75 \times 25 \mathrm{~cm})$ were set up on the floor to accommodate the chicks in a climate-controlled housing. Wood shaving was placed to a depth of $2 \mathrm{~cm}$ as litter material on the floor, which was replaced every week. The birds were brooded at $33^{\circ} \mathrm{C}$ for the first two days, and then the temperature was reduced gradually to $24^{\circ} \mathrm{C}$ at 19 days of age, and maintained at this level to the end of the experiment. Feed, in pellet form, and
Table 1. Feeding regimes adopted in the main experiment

\begin{tabular}{lccc}
\hline \multirow{2}{*}{ Treatment groups } & \multicolumn{3}{c}{ Feed allocation by time (d) } \\
\cline { 2 - 4 } & $1-7$ & $8-14$ & $15-21$ \\
\hline AP & AP & AP & AP \\
SBM-AP & SBM & AP & AP \\
CM-AP & CM & AP & AP \\
AP-SBM & AP & SBM & SBM \\
AP-CM & AP & CM & CM \\
\hline
\end{tabular}

$\mathrm{AP}$, animal protein diet containing fish meal as a major part (50), along with soybean (25) and canola (25) meals; SBM, vegetable protein diet containing predominantly soybean meal (75) along with canola meal (25); $\mathrm{CM}$, vegetable protein diet containing predominantly canola meal (75) and soybean meal (25).

water were provided ad libitum.

Three experimental diets, coded as SBM, CM, and AP, were formulated with maize, wheat and vegetable oil as the main energy sources, along with soybean, canola, and fish meal as protein sources, in addition to other feedstuffs as shown in Table 2. Diets SBM and CM were entirely vegetable-based, and contained soybean and canola meals as the main sources of proteins in a ratio of 3:1 to one another, whereas an AP diet contained soybean, canola and fish meals as protein sources in a 2:1:1 ratio along with other feedstuffs. These three basal diets (SBM, CM, and AP) were allocated alternately to the chicks as described in Table 1. All diets were iso-caloric and iso-nitrogenous, and supplemented with carbohydrases and phytase enzymes (Danisco Animal Nutrition, Malborough, Wiltshire, UK), and Zinc Bacitracin. The birds were fed on the test diets from hatch to 21 days of age. Feed intake, body weight gain (BWG), and feed conversion ratio were assessed weekly. Mortality was also recorded when it occurred. Two birds from each replicate were randomly selected on day 21 , weighed, and slaughtered by cervical dislocation, to measure the weight of visceral organs (small intestine, pancreas, liver, proventriculus, ventriculus or gizzard, spleen, bursa of Fabricius). In addition, tissue samples from the pancreas and the proximal region of the jejunum were also collected to assess the tissue protein content (pancreas and jejunum), and specific activities of digestive enzymes (chymotrypsin amidase, maltase, sucrase, alkaline phosphatise, and lipase). The right tibia bone was also collected at this time $(21 \mathrm{~d})$ from two birds, killed in a similar way, to measure the bone characteristics (weight, length, width, tibia ash content) and bone strength. All samples were pooled by pen and stored at $-20^{\circ} \mathrm{C}$ until further processing for laboratory analyses.

\section{Bone processing and enzyme analysis}

The tibia bones were boiled for 10 minutes in deionized water, to remove all the soft tissue and defatted. Length and head width were measured using digital callipers (Mitutoyo, Kawasaki, Japan) and the weight was recorded. The bones 
Table 2. Composition of diets fed the birds

\begin{tabular}{|c|c|c|c|}
\hline & \multicolumn{3}{|c|}{ Diets } \\
\hline & SBM & $\mathrm{CM}$ & $\mathrm{AP}$ \\
\hline \multicolumn{4}{|l|}{ Ingredient composition $(\mathrm{g} / \mathrm{kg})$} \\
\hline Maize & 406.6 & 363.6 & 420.4 \\
\hline Wheat & 211.0 & 181.7 & 209.6 \\
\hline Vegetable oil & 0.0 & 21.7 & 0.0 \\
\hline Soybean meal & 246.9 & 96.4 & 156.3 \\
\hline Canola meal & 82.3 & 290 & 77.5 \\
\hline Fish meal & 0.0 & 0.0 & 77.4 \\
\hline Limestone & 20.1 & 14.6 & 16.2 \\
\hline Dicalcium phosphate & 17.0 & 21.0 & 20.0 \\
\hline DL-methionine & 2.0 & 1.7 & 1.4 \\
\hline L-lysine & 1.7 & 1.2 & 2.0 \\
\hline Sodium chloride & 3.5 & 4.0 & 4.0 \\
\hline Vitamin-mineral premix ${ }^{1}$ & 2.2 & 2.2 & 2.2 \\
\hline Choline chloride & 0.6 & 0.6 & 0.6 \\
\hline Avizyme1502 & 0.5 & 0.5 & 0.5 \\
\hline PhyzymeXP & 0.1 & 0.1 & 0.1 \\
\hline Sodium bicarbonate & 0.0 & 0.0 & 5.8 \\
\hline Zinc bacitracin & 0.5 & 0.5 & 0.5 \\
\hline Marker $\left(\mathrm{TiO}_{2}\right)$ & 5.0 & 5.0 & 5.0 \\
\hline \multicolumn{4}{|l|}{ Nutrient composition $(\mathrm{g} / \mathrm{kg})$} \\
\hline $\mathrm{ME}(\mathrm{MJ} / \mathrm{kg})$ & 12.37 & 12.37 & 12.37 \\
\hline Crude protein & 211.0 & 211.2 & 211.3 \\
\hline Crude fibre & 31.0 & 36.0 & 28.3 \\
\hline Ether extract & 24.0 & 28.1 & 29.5 \\
\hline Calcium & 12.2 & 12.2 & 12.3 \\
\hline Available P & 6.1 & 6.2 & 6.3 \\
\hline Sodium & 2.0 & 2.0 & 2.2 \\
\hline Chlorine & 2.5 & 2.7 & 2.7 \\
\hline Lysine & 13.0 & 13.0 & 13.3 \\
\hline Methionine+cystine & 8.3 & 8.3 & 8.4 \\
\hline Threonine & 8.3 & 8.4 & 8.4 \\
\hline Arginine & 14.0 & 14.0 & 14.1 \\
\hline
\end{tabular}

SBM, soybean meal; CM, canola meal; AP, animal protein.

${ }^{1}$ Provided per $\mathrm{kg}$ of diet $(\mathrm{mg})$ : vitamin A (as all-trans retinol), $3.6 \mathrm{mg}$; cholecalciferol, $0.09 \mathrm{mg}$; vitamin $\mathrm{E}$ (as d- $\alpha$-tocopherol), $44.7 \mathrm{mg}$; vitamin $\mathrm{K}_{3}, 2 \mathrm{mg}$; thiamine, $2 \mathrm{mg}$; riboflavin, $6 \mathrm{mg}$; pyridoxine hydrochloride, $5 \mathrm{mg}$; vitamin $\mathrm{B}_{12}, 0.2 \mathrm{mg}$; biotin, $0.1 \mathrm{mg}$; niacin, $50 \mathrm{mg}$; D-calcium pantothenate, $12 \mathrm{mg}$; folic acid, $2 \mathrm{mg}$; Mn, $80 \mathrm{mg}$; Fe, 60 $\mathrm{mg}$; Cu, $8 \mathrm{mg}$; I, $1 \mathrm{mg}$; Co, $0.3 \mathrm{mg}$; Mo, $1 \mathrm{mg}$.

were then placed horizontally between brackets set $10 \mathrm{~mm}$ apart, to measure the breaking strength. A $10 \mathrm{~mm}$ (diameter) compression rod (Lloyd, Hampshire, UK) was positioned and pressure was applied to the bones.

Digestive enzyme activities and protein concentrations were assessed on jejunal tissues after the samples were processed according to the method described by (ShiraziBeechey et al., 1991) and modified for poultry (Iji et al., 2001b). The pancreatic tissue was processed in a similar way to the jejunal tissues, except that Milli-Q water (Millipore, North Ryde, NSW 2113, Australia) was used in lieu of buffer, and the entire organ was homogenized
(Nitsan et al., 1974; Iji et al., 2001b). The specific activities of jejeunal and pancreatic enzymes were assessed by incubation with fixed substrate concentrations as standardized for poultry (Iji et al., 2001b). Both jejunal and pancreatic tissue protein concentrations were measured according to the procedure described by (Bradford, 1976) using Comassie dye-binding. All the raw data for protein concentration were processed through the Lowry Software (McPherson, 1985) before statistical analysis.

\section{Feed selection test}

A sub-group of 30 day-old male chicks of similar strain and initial weight as those in the main experiment were subdivided into 6 cages (replicates), with five chicks per cage. All chicks were fed on a commercial diet until 7 days of age, then provided access to two VP (SBM and CM) diets in separate feeders from 8 to 21 days of age. Two feeders were placed side by side of one part of the pen to make easy preference for eating feeds. Feed intake from each feeder was calculated daily until the end of the experiment.

\section{Animal ethics approval and statistical analysis}

All animal care, handling and management of this experiment were approved by the Animal Ethics Committee of the University of New England, Australia (Approval No: AEC11/068), Australia. Statistical analyses were performed using Minitab software (2000). The data were subjected to one-way analyses of variance for completely randomized design and tested for significance between the dietary treatment means by Fisher's least significant difference at $\mathrm{p} \leq 0.05$.

\section{RESULTS}

\section{Gross performance of broiler chickens on main experiment}

Apart from the first 7 days, dietary regime had no effect $(p>0.05)$ on feed intake (FI) when assessed from hatch to 14 or 21 days (Table 3). Chicks in the CM-AP and AP dietary groups ate more $(\mathrm{p}<0.05)$ than chicks in the other diet groups between hatch and 7 days. Up to 7 days, birds in the SBM-AP diet group gained the most $(\mathrm{p}<0.001)$ weight, while birds on the CM-AP diet regime gained the least. From hatch to 14 days, birds on the SBM-AP regime gained the highest $(p<0.001)$ weight, while birds on the CM-AP regime gained the least. Body weight gain (BWG) in birds on the SBM-AP was similar to that of birds fed the AP diet to 14 days, but was significantly different $(\mathrm{p}<0.001)$ from the other groups. Birds on the AP-CM regime had the best feed conversion ratio (FCR), while birds in the CM-AP group had the poorest FCR at 7 days. The FCR on SBM-AP diet plan was also better $(\mathrm{p}<0.05)$ than on the AP-CM regime, the latter being the worst in FCR to 14 days. There 
Table 3. Feed intake (FI), body weight gain (BWG), feed conversion ratio (FCR) and mortality of broilers from d1 to 21 days of age

\begin{tabular}{lccccccc}
\hline & Age $(\mathrm{d})$ & AP & SBM- AP & CM-AP & AP-SBM & AP-CM & SEM \\
\hline FI $(\mathrm{g} / \mathrm{b})$ & $1-7$ & $180.8^{\mathrm{ab}}$ & $171.7^{\mathrm{b}}$ & $196.5^{\mathrm{a}}$ & $177.3^{\mathrm{b}}$ & $171.5^{\mathrm{b}}$ & $2.64^{*}$ \\
& $1-14$ & 631.3 & 631.6 & 645.0 & 623.8 & 649.6 & 5.31 \\
& $1-21$ & 1324.0 & 1338.7 & 1349.7 & 1317.6 & 1354.8 & 8.55 \\
BWG (g/b) & $1-7$ & $161.8^{\mathrm{bc}}$ & $160.8^{\mathrm{c}}$ & $146.2^{\mathrm{d}}$ & $170.9^{\mathrm{a}}$ & $168.5^{\mathrm{ab}}$ & $1.10^{* * *}$ \\
& $1-14$ & $523.3^{\mathrm{ab}}$ & $530.0^{\mathrm{a}}$ & $496.4^{\mathrm{c}}$ & $507.3^{\mathrm{bc}}$ & $498.0^{\mathrm{c}}$ & $2.60^{* * *}$ \\
& $1-21$ & 916.7 & 960.7 & 902.5 & 893.2 & 896.3 & 8.66 \\
FCR & $1-7$ & $1.12^{\mathrm{b}}$ & $1.07^{\mathrm{bc}}$ & $1.34^{\mathrm{a}}$ & $1.04^{\mathrm{bc}}$ & $1.02^{\mathrm{c}}$ & $0.014^{* * *}$ \\
& $1-14$ & $1.20^{\mathrm{b}}$ & $1.19^{\mathrm{b}}$ & $1.30^{\mathrm{a}}$ & $1.23^{\mathrm{ab}}$ & $1.30^{\mathrm{a}}$ & $0.012^{*}$ \\
& $1-21$ & 1.45 & 1.40 & 1.50 & 1.48 & 1.51 & 0.014 \\
Mortality (\%) & $1-21$ & 4.76 & 2.36 & 2.36 & 2.36 & 2.36 & 1.126 \\
\hline AP, an
\end{tabular}

AP, animal protein; SBM, soybean meal; CM, canola meal; SEM, pooled standard error of mean.

Each value represents the mean of 6 replicates consisting of 7 birds in each replicate cage from d1-21 days.

${ }^{\mathrm{a}, \mathrm{b}, \mathrm{c}}$ Means bearing uncommon superscripts within a row are significantly different at $* \mathrm{p}<0.05$ and $* * * \mathrm{p}<0.001$

were no significant differences ( $p>0.05$ ) in FI, BWG, FCR, and mortality between the groups when assessed between hatch and 21 days. Although chicks on SBM-AP diet group attained the highest BWG $(960.7 \mathrm{~g})$, the differences between the treatments were non-significant $(p=0.12)$ at the end of the trial period (21 d).

\section{Gastro-intestinal development and digestive enzyme activities}

The relative weight of visceral organs of chicks fed on the different plans to 21 days is shown in Table 4. The weight of all the organs (small intestine, proventriculus, ventriculus or gizzard, pancreas, liver, spleen, and bursa of
Fabricius) of birds was identical ( $p>0.05)$ between treatments. The relative weight of the spleen was slightly higher $(\mathrm{p}<0.08)$ in chicks on the AP-CM plan than in other groups. There was also no significant $(p>0.05)$ difference in tissue protein contents, or pancreatic and intestinal digestive enzymes activities between treatments (Table 5).

\section{Bone (tibia) development}

There were no significant $(\mathrm{p}>0.05)$ differences in the various bone characteristics that were assessed (Table 6). However, birds on the SBM-AP regime had the highest tibia ash content $(1.20 \mathrm{mg})$, while the birds on the AP-SBM diet plan had the lowest tibia ash content $(1.01 \mathrm{mg})$, but

Table 4. Relative weight of visceral organs ( $\mathrm{g} / 100 \mathrm{~g}$ of body weight) of broiler chickens at different feeding plans at 21 days

\begin{tabular}{lcccccc}
\hline & AP & SBM-AP & CM-AP & AP-SBM & AP-CM & SEM \\
\hline Small intestine $^{1}$ & 4.8 & 4.9 & 5.3 & 4.9 & 5.9 & 0.18 \\
Proventriculus+gizzard $^{2}$ & 3.4 & 3.5 & 4.0 & 3.7 & 3.6 & 0.13 \\
Pancreas & 0.26 & 0.25 & 0.30 & 0.29 & 0.32 & 0.008 \\
Liver & 3.6 & 3.4 & 3.8 & 3.7 & 3.8 & 0.10 \\
Spleen & 0.09 & 0.09 & 0.07 & 0.07 & 0.11 & 0.005 \\
Bursa of fabricius & 0.14 & 0.15 & 0.13 & 0.13 & 0.13 & 0.008 \\
\hline
\end{tabular}

AP, animal protein; SBM, soybean meal; CM, canola meal; SEM, pooled standard error of mean.

Each value represents the mean of 6 replicates of 7 birds each replicate cage at 21 days.

${ }^{1,2}$ Organs (small intestine, proventriculus plus gizzard) were weighed with contents. $* p>0.05$, Non-significant.

Table 5. Tissue protein and enzyme activities of broiler chicks at 21 days of age on different feeding regimes

\begin{tabular}{|c|c|c|c|c|c|c|}
\hline & $\mathrm{AP}$ & SBM- AP & CM-AP & AP-SBM & $\mathrm{AP}-\mathrm{CM}$ & SEM \\
\hline Pancreatic protein $(\mathrm{mg} / \mathrm{g})$ & 46.0 & 32.0 & 33.0 & 37.4 & 46.7 & 2.44 \\
\hline Chymotrypsin amidase $^{1}$ & 3.4 & 5.8 & 4.4 & 4.2 & 4.0 & 0.28 \\
\hline Jejunal protein (mg/g) & 30.0 & 33.0 & 36.6 & 35.2 & 36.0 & 1.52 \\
\hline Maltase ( $\eta \mathrm{mol} / \mathrm{mg})$ & 0.62 & 0.58 & 0.48 & 0.47 & 0.52 & 0.027 \\
\hline Sucrase (ๆmol/mg) & 0.13 & 0.13 & 0.14 & 0.12 & 0.13 & 0.006 \\
\hline Alkaline phosphatase ${ }^{2}$ & 3.6 & 3.0 & 3.0 & 3.1 & 4.3 & 0.24 \\
\hline Lipase $^{3}$ & 2.97 & 2.92 & 3.84 & 3.76 & 2.64 & 0.247 \\
\hline
\end{tabular}

AP, animal protein; SBM, soybean meal; CM, canola meal; SEM, pooled standard error of mean.

Data represent means of six replicates at 21 days of age.

${ }^{1}$ Chymotrypsin amidase ( $\eta \mathrm{mol} / \mathrm{mg}$ protein). ${ }^{2}$ Alkaline phosphatase. ${ }^{3}$ Pancreatic lipase ( $\mu \mathrm{mol} / \mathrm{min} / \mathrm{mg}$ protein). 
Table 6. Bone (tibia) characteristics of broiler chickens from different feeding regimes at 21 days of age

\begin{tabular}{lcccccc}
\hline & AP & SBM-AP & CM-AP & AP-SBM & AP-CM & SEM \\
\hline Length of bone (mm) & 63.3 & 65.8 & 64.5 & 64.8 & 65.4 & 0.58 \\
Weight of bone (g/kg body weight) & 4.3 & 4.5 & 4.4 & 4.5 & 4.2 & 0.06 \\
Width of bone (mm) & 9.3 & 10.0 & 9.4 & 9.1 & 9.2 & 0.11 \\
Breaking strength (kg/g bone) & 4.4 & 4.1 & 4.2 & 3.8 & 3.7 & 0.10 \\
Total tibia ash (mg/g bone) & 1.08 & 1.20 & 1.07 & 1.01 & 1.03 & 0.020 \\
\hline
\end{tabular}

AP, animal protein; SBM, soybean meal; CM, canola meal; SEM, pooled standard error of mean.

Length and width are measured in millimetres per bone per bird basis; data represent means of two chickens from six replicate groups at 21 days of age.

differences were not significant $(\mathrm{p}>0.05)$ between treatments.

\section{Feed selection}

In the choice-feeding experiment, the birds ate more of the CM diet than the SBM diet from 8 to 14 days $(\mathrm{p}<0.001)$ and from 15 to 21 days ( $\mathrm{p}<0.01$ ) (Figure 1). From 8 to 14 days, the choice was $62.2 \%$ in favour of $\mathrm{CM}$ while from 15 to 21 days; selection was $58.42 \%$ for $\mathrm{CM}$, and $41.58 \%$ for SBM, respectively.

\section{DISCUSSION}

\section{Gross responses of broiler chickens}

The results demonstrated that birds on the different diet plans achieved similar body weight gain with identical FCR at 21 days, except during the early growing period (hatch to $14 \mathrm{~d}$ ). The results revealed that the birds fed on the AP diet grew better than those that were fed solely on VP diets (SBM and CM) at the earlier stage of growth. These differences disappeared in the later period of growth, although the trial period ( 1 to 21 days) is still a period of rapid growth rate for broiler chickens.

The lack of differences in FI between the feeding regimes would suggest that broiler chicks ate to meet breed or genetic standards and will achieve these targets in FI, if the nutrient composition is ideal. The nature of the starting diets (AP or VP) did not seem to confer any advantage in

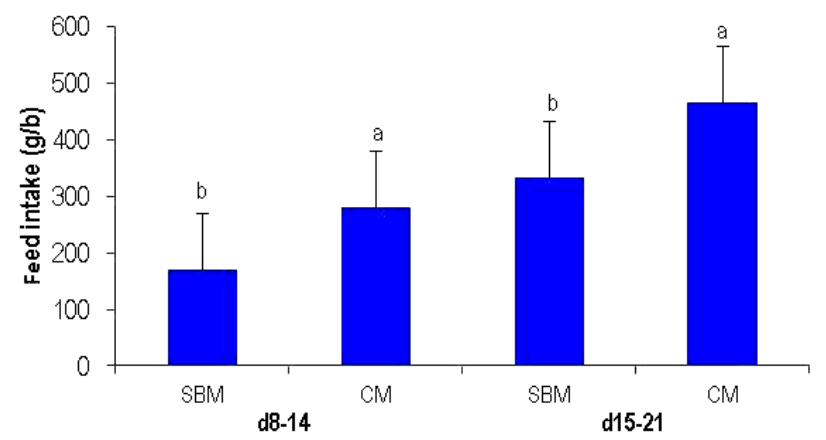

Figure 1. Feed selection by broilers on two VP diets (SBM; CM) from d 8-14, and d 15-21 in choice-fed experiment. VP, vegetable protein; SBM, soybean meal; CM, canola meal. ${ }^{\mathrm{a}, \mathrm{b}}$ Means bearing uncommon superscript are significantly different at $\mathrm{p}<0.001$ from $\mathrm{d} 8-14$, and at $\mathrm{p}<0.01$ from $\mathrm{d} 15-21$ days. the long term. Providing the VP and then AP diets enabled the birds to grow equally well, unlike what was observed in previous studies when they were raised on similar VP diets from hatch to $35 \mathrm{~d}$ (Hossain et al., 2013a). Furthermore, the similarity in response of birds regardless of the protein source of the starter diet may be explained by the complementary effect of AP and VP diets for each treatment group. Most probably, chicks started on one diet and then transferred to another diet may undergo compensatory growth and still perform to the breed standard.

\section{Gastro-intestinal development of broiler chickens on test diets}

Morphometric measures of digestive organ development revealed no significant difference between the treatments. Gastro-intestinal development could be uniform due to similarity in body growth. The same response could apply to development of visceral organ development. These results agreed with those of previous researchers (Al-Masri, 2006; Xavier et al., 2012) who observed similar growth of digestive organs in broiler chicks on diets based on animal or VP ingredients. It is generally known that visceral organs associated with digestive function develop most rapidly in the first 7 to 10 days of life (Nitsan et al., 1991; Iji et al., $2001 \mathrm{a}, \mathrm{b})$. However, how the nature of the starter diets influences this development has not been adequately studied.

The thymus, spleen and bursa of Fabricius are the main immune organs of the chicken. A higher spleen weight, but not the thymus or bursa observed herein, would suggest better ability to protect from infection (Liu et al., 2011). Higher protein intake may result in increased spleen weight and improved immunity of the birds. The increased relative weight of the spleen may alter the development and promotion of immune function of the animal (Liu et al., 2011), but this was not assessed in the current study.

\section{Tissue protein growth and digestive enzyme activities}

There was no significant difference between treatments in terms of digestive enzyme function, or pancreatic and intestinal tissue protein contents of broiler chickens. This lack of differences may be responsible for the uniformity in growth, in spite of differences in feeding regimes. The current findings are similar to those of a previous study 
(Hossain et al., 2013b), which reported no significant differences in the tissue protein content and endogenous enzyme activities in broiler chicks fed on all-vegetable diets with or without supplemental enzymes. However, there are no previous reports on the effect of VP diets on intestinal structure and function. Enzymes tend to respond to the presence of target substrates in the lumen of the intestine.

\section{Bone development}

In this study, broiler chicks on the different feeding regimes developed similar bone characteristics. This may be an outcome of the identical body growth. The results are in contrast to the findings of Hossain et al. (2013a), when similar diets were used throughout the test cycle. Amongst bone characteristics measured, total bone ash was found to be slightly higher in the SBM-AP group compared to other groups. The higher concentration of bone ash in this group of chickens may be a result of the numerically longer, heavier and wider bones of the birds. Hossain et al. (2013a) reported an increase in bone ash content in broiler chicks when they were fed on animal protein-containing diets, compared to those on vegetable diets. Animal protein sources such as fishmeal tend to contain high levels of minerals contents, and are devoid of phytic acid, the antinutritive factor that is responsible for binding minerals in plant protein sources.

\section{Feed selection}

The results demonstrated that birds preferred the CM diet when they were given a choice between the two VP diets in this study. Birds consumed $20 \%$ more CM diet than the SBM diet. A similar trend was also observed in a previous study in an experiment on similar diets (Hossain et al., 2013a), in which these diets were fed separately to different groups of birds. The reason for this preference for $\mathrm{CM}$ diet is not obvious, but feed selection is influenced by several factors, for example, nutrient requirements of individual birds, crude fibre content, chronological age, prior experience, feed composition, nutritive value, stage of production, physical and chemical properties of protein sources, amino acids, vitamins and minerals, and unidentified growth factors. Apart from these factors, sensory properties of food materials such as colour, smell, flavour, taste or palatability might also play a key role in feed selection of broiler chickens (Cruze et al., 2005). Addition of oil to $\mathrm{CM}$ diets might reduce the dustiness of the feeds and encourage higher feed intake. This supplementation of oil to CM diet might enhance the palatability of the feeds. Palatability of diets, metabolic and nutritional requirements might have a profound effect in dietary self-selection of birds (Hughes, 1984; Forbes, 1995). Furthermore, as is evidence from the formulation profile, the higher fibre content of CM diets perhaps induced slightly higher feed intake. Besides, higher feed consumption may be a result of faster growth rate of individual birds and the consequent higher nutritional requirements (Shrivastava et al., 1981).

The variability found in feed selection might reflect the individual variation in nutrient requirement, variation in the actual composition of the feeds or variation of the physical form of the test diets (Cerrate et al., 2007). It appeared that all diets were similar in feed textures, and pelleted well by visual observation, despite these uniformity, some feeds may have poor quality. Some researchers showed that physical forms influence the feed selection (Rose et al., 1986; Yo et al., 1997).

Certain minerals such as $\mathrm{Na}, \mathrm{Cl}$, and $\mathrm{Zn}$ in the formulated diets might affect the feed consumption of birds by increasing the palatability of the given diets to the broiler chickens. Trace mineral (e.g. $\mathrm{Zn}$ and $\mathrm{Cu}$ ) digestibility was found to be increased in the birds fed on CM diet compared to those fed on SBM diets (Hossain et al., 2013b). The increased mineral digestibility of CM diet may slightly affect the feed consumption of birds, because trace minerals in association with enzymes play an active role in processes like digestion, absorption and assimilation of nutrients.

\section{CONCLUSION}

Birds grew equally well regardless of the nature of the starter diet. This may be due to complementary supply of nutrients at different stages of growth. The preference of chicks for the CM diet warrants further investigation as this diet did not appear to be nutritionally better than SBM in terms of growth rate and feed efficiency.

\section{ACKNOWLEDGMENTS}

The project was funded by University of the New England, Australia, and Danisco Animal Nutrition, UK, provided the enzymes.

\section{REFERENCES}

Al-Masri, M. R. 2006. Productive performance and digestive tract size of broiler chicks fed a conventional or all-vegetable ingredient diets. J. Appl. Anim. Res. 30:81-84.

Bradford, M. 1976. A rapid and sensitive method for the quantitation of microgram quantities of protein utilizing the principle of protein-dye binding. Anal. Biochem. 72:248-254.

Cruze, V. C., A. C. Pezzato, D. F. Pinheiro, J. C. Goncalves, and J. R. Sartori. 2005. Effects of free-choice feeding on the performance and ileal digestibility of nutrients in broilers. Braz. J. Poult. Sci. 7:143-150.

Cerrate, S., Z. Wang, C. Coto, F. Yan, and P. W. Waldroup. 2007. Choice feeding as a means of identifying nutritional needs with two methods of amino acid formulation. Intl. J. Poult. Sci. 6:846-854. 
Faria, F. D. E., P. S. Rosa, B. S. Viera, M. Macari, and R. L. Furlan. 2005. Protein levels and environmental temperature effects on carcass characteristics, performance, and nitrogen excretion of broiler chickens from 7 to 21 days of age. Braz. J. Poult. Sci. 7:247-253.

Forbes, J. M. 1995. Voluntary Food Intake and Diet Selection in Farm Animals. CAB International, Wallingford, UK. p. 532.

Hughes, B. O. 1984. The principles underlying choice-feeding behaviour in fowls with special reference to production experiments. World's Poult. Sci. J. 40:141-150.

Hargis, P. H. and C. R. Creger. 1980. Effects of varying dietary protein and energy levels on growth rate and body fat in broilers. Poult. Sci. 59:1499-1504.

Hruby, M., M. L., Hamre, and C. N. Coon. 1995. Free choice feeding and three temperature treatments. J. Appl. Poult. Res. 4: 356-365.

Hossain, M. A., A. F. Islam, and P. A. Iji. 2012. Energy utilization and performance of broiler chickens raised on diets with vegetable proteins or conventional feeds. Asian J. Poult. Sci. 6:117-128.

Hossain, M. A., A. F. Islam, and P. A. Iji. 2013a. Growth responses, excreta quality, nutrient digestibility, bone development and meat yield traits of broiler chickens fed on vegetable or animal protein diets. S. Afr. J. Anim. Sci. 43: 208-218.

Hossain, M. A., A. F. Islam, and P. A. Iji. 2013b. Impact of exogenous enzymes on micronutrient digestibility, tissue protein contents, and internal enzyme activities of broilers fed on all-vegetable diets. In: Proc. 8th Int. Poult. Show and Semnr., WPSA-BB, Bangladesh. 135-141.

Hossain, M. A. 2013c. Improving Vegetable Protein Diets for Broiler Chickens. Ph. D. Thesis, University of New England, Armidale, Australia.

Hossain, M. A., A. F. Islam, and P. A. Iji. 2011b. Effects of allvegetable diets on leg abnormalities of broiler chickens. Australas. Med. J. 4:761.

Iji, P.A., A. Saki, and D. R. Tivey. 2001a. Body and intestinal growth of broiler chicks on a commercial starter diet. 1 . Intestinal weight and mucosal development. Br. Poult. Sci. 42:505-513.

Iji, P. A., A. Saki, and D. R. Tivey. 2001b. Body and intestinal growth of broiler chicks on a commercial starter diet. 2 . Development and characteristics of intestinal enzymes. Br. Poult. Sci. 42:514-522.

Liu, H., P. Luo, S. Chen, and S. Shang. 2011. Effects of squid ink on growth performance, antioxidant functions ad immunity in growing broiler chickens. Asian Australas. J. Anim. Sci. 24:1752-1756.

Moran, E. T. 1985. Digestion and absorption of carbohydrates in fowl and events through perinatal development. J. Nutr.115: 665-674.

McPherson, G. A. 1985. Lowry program: Elsevier-BIOSOFT, 68 Hills Rd, Cambridge, CB2, ILA, UK.

Mastika, I. M. 1983. Performance of two strains of growing pullets offered free choice of diets. In: Recent Advances in Animal Nutrition in Australia (Eds. D. J. Farrel and P. Vohra). University New England, Australia, p. 21A.
Mastika, I. M. and R. B. Cumming. 1981. Performance of two strains of broiler chickens offered free choice from different ages. In: Proceedings 4th Australia Poultry and Stock Feed Convention, Perth, Australia. pp.79-85.

Minitab. 2000. Minitab Statistical Software User's Guide 2: Data Analysis and Quality Tools. Minitab Inc., State College, PA, USA.

Nitsan, Z., G. Ben-Avraham, Z. Zerof, and I. Nir. 1991. Growth and development of the digestive organs and some enzymes in the broiler chicks after hatching. Br. Poult. Sci. 32:515-523.

Nitsan, Z., Y. Dror, I. Nir, and N. Shapira. 1974. The effects of force-feeding on enzymes of the liver, kidney, pancreas and digestive tract of chicks. Br. J. Nutr. 32:241-247.

Noble, D. O., M. L. Picard, E. A. Dunnington, G. Uzu, A. S. Larsen, and P. B. Siegel. 1993. Food intake adjustment of chicks: Short term reactions of genetic stocks to deficiencies in lysine, methionine or tryptophan. Br. Poult. Sci. 34:725-735.

Picard, M., P. B. Siegel, P. A. Geraert, G. Uzu, and P. E. V. Williams. 1997. Five genetic stock of broilers of different growth potential choose the same protein/energy balance. Pages 117-118. In: Animal Choices (Eds. J. M. Forbes, T. L. J. Laurence, and M. A. Varley). Br. Soc. Anim. Sci. Occas. Publ. 20:117-118.

Rose, S. P. and I. Kyriazakis 1991. Diet selection of pigs and poultry. Proc. Nutr. Soci. 50:87-98.

Rose, S. P., A. Burnett, and R. A. Elmajeed. 1986. Factors affecting the diet selection of choice-fed broilers. Br. Poult. Sci. 27:215-224.

Swatson, H. K., P. A. Iji, and R. M. Gous. 2003. Body growth, visceral organ weight and intestinal digestive enzyme of chickens on diets varying in energy and protein contents. J. Anim. Vet. Adv. 2:305-311.

Shrivastava, H. P., V. R. Sadagopan, T. S. Johri, and S. Chand. 1981. Sunflower seed meal for poultry-A review. Indian Poult. Gaz. 65:100-112.

Shirazi-Beechey, S. P., M. W. Smith, Y. Wang, and P. S. James. 1991. Post-natal development of lamb intestinal digestive enzymes is not regulated by diet. J. Physiol. 437:691-698.

Ullah, M. S., T. N. Pasha, Z. Ali, F. Saima, F. M. Khattak, and Z. Hayat. 2012. Effects of different pre-starter diets on broiler performance, gastrointestinal tract morphometry and carcass yield. J. Anim. Plant Sci. 22:570-575.

Xavier, S. A. G., J. H. Stringhini, A. B. de Brito, M. B. Cafe, N. S. M. Leandro, M. A. Andrade, and M. Laboissiere. 2012. Poultry viscera and bone meal in broiler pre-starter and starter diets. R. Bras. Zootec. 41:934-940.

Yo, T., P. B. Siegel, H. Guerin, and M. Picards. 1997. Selfselection of dietary protein and energy by broilers grown under a tropical climate: Effect of feed particle size on the feed choice. Poult. Sci. 76:1467-1473.

Zulkifli, I., H. S. ImanRahayu, A. R. Alimon, M. K. Vidyadaran, and S. A. Babjee. 2001. Response of choice-fed Red Jungle Fowl and commercial broiler chickens offered a complete diet, corn and soybean. Asian Australas. J. Anim. Sci. 14:1758-1762. 